\title{
Evaluation of Seaweed Extract Impact on Growth and Yield of Tomato Plants under Salinity Stress Conditions
}

\author{
Ashmawi, E. A'., Abd Elwahed, A. H. $\mathbf{M}^{1}$ and Awaad, A.H.H ${ }^{1}$ \\ 1- Department of Horticulture, Faculty of Agriculture, AL-Azhar University, Cairo.
}

\begin{abstract}
This experiment was conducted at the Faculty of Agriculture, AL-Azhar University, Nasr City, Cairo, Egypt during the two winter seasons of 2018-2019 and 2019-2020 to study the effect of saline levels in the diluted agricultural drainage water of 1000, 2000, 3000, $4000 \mathrm{ppm}$ and tap water as a control (300 ppm) and foliar seaweed extract concentrations of 400,600,800 ppm and tap water as a control and their interaction on the growth, yield and fruits quality of tomato (Lycopersicon esculentum L.) Magy hybrid under plastic house conditions. The obtained results showed that plant height, leaf area, fruit fresh weight, size, length and diameter, leaf chlorophyll A, B and carotenoids contents, in addition to total yield as fruit number and weight significantly increased with using the saline level of $1000 \mathrm{ppm}$ and the foliar seaweed extract concentration of $800 \mathrm{ppm}$. On contrast, fruit contents of T.S.S and dry matter significantly increased with increasing the saline water levels up to $4000 \mathrm{ppm}$ and the seaweed extract concentrations at $800 \mathrm{ppm}$. Also, the data indicated that fruit content of ascorbic acid significantly increased from using the $2000 \mathrm{ppm}$ level saline water and the concentration of 800 ppm seaweed extract. In this respect, it could be concluded that the application of the seaweed extract concentration at $800 \mathrm{ppm}$ was the most effective to decrease the adverse effect of saline irrigation water on the growth and yield of tomato plants.
\end{abstract}

Key words: Salinity, seaweed extract, growth and tomato.

\section{Introduction}

Tomato (Lycopersicon esculentum L.) is one of the most important vegetable crops grown in Egypt either local consumption or exportation. The cultivated area of this crop in 2018 was estimated at 475,505 feddan, which produced about 7.9 million tons with an average yield of 16.61 tons per feddan (FAO, 2018). Salt stress is one of the major strong inhibitor of plant growth and development. Some events that prevail during this stress are declined uptake of water, elevated respiration rate, change in mineral distribution, membrane instability and failure in the maintenance of turgor pressure (Foolad, 2004). These harmful effects cause an oxidative damage that may end up in decreasing growth of plants and its yield (Zhu, 2001). Enhancement for salinity tolerance would give significant values for a moderately sensitive crop like tomato when it is grown under the conditions of salinity. Different methods are being exercised to ameliorate the adverse effects of salinity such as exogenous foliar applications of compatible solutes as well as application of various organic solutes. Here, it is well known that seaweed extract is useful for ensuring higher agricultural production and it is an important resource for diverse components which have beneficial effects, in terms of enhancement of plant growth and development (Hernández- Herrera et al., 2014), improving tolerance to environment stress and increasing antioxidant properties of plants (Zhang et al., 2003). Therefore, the objective of present study was to evaluate the effect of different concentrations of seaweed extract applied as foliar spray on the growth and the changes in the physical and chemical characteristics of tomato plants grown under salinity stress.

\section{Materials and Methods}

This experiment was carried out at the farm of the Faculty of Agriculture, Al-Azhar University, Nasr city, Cairo, Egypt during the two winter seasons of 2018-2019 and 2019-2020 to study the effect of the different concentrations of irrigation with saline agriculture drainage water, seaweed extract (SWE) and their combination on growth and yield of tomato (Lycopersicon esculentum L) Magy hybrid under plastic house conditions. The used drainage water was brought from Karoun Lake at El- Fayoum Governorate where the salt concentration was reached $28000 \mathrm{ppm}$. This saline water was diluted to the required four salt concentrations 1000, 2000, 3000 , $4000 \mathrm{ppm}$ and the control plants was irrigated with tap water at the concentration of $300 \mathrm{ppm}$. The chemical analyses of the used diluted drainage water were shown in Table (1). Under plastic house conditions, one tomato seedlings were transplanted in plastic pot of $40 \mathrm{~cm}$ diameter; contain $15 \mathrm{~kg}$ of dried sandy clay loam soil on October $15 \mathrm{st}$ in the two seasons. The obtained results of the physical and chemical analyses of soil experimental site were shown in Table (2). The Plastic pots were arranged in a randomized complete blocks design in factorial arrangement with three replications. Each replicate had 20 treatments, and each treatment consisted of three pots. Irrigation with saline water was initiated after 10 days from transplanting. Plants were irrigated with saline water twice per a week and each pot received 2.5 liters of water to maintain soil continuously moistened in the 
pot. Plants were sprayed with four concentrations of seaweed extract (SWE), namely 400, 600, 800 ppm and tap water as a control at 4 times starting 20 days after transplanting and repeated at 10 days intervals during the growth seasons. The seaweed extract was obtained from Union for Agricultural Development
(UAD) Company, Cairo, Egypt. The chemical and biochemical analysis of seaweed extract are shown in Table (3). The recommended agricultural practices of growing tomato were applied whenever needed (Hassan, 1988).

Table 1.The chemical analyses of the used saline drainage water (meq/L.).

\begin{tabular}{cclcccccc}
\hline Concentrations & $\mathbf{C o 3}^{--}$ & $\mathbf{H C O}_{3}{ }^{-}$ & $\mathbf{C l}^{-}$ & $\mathbf{S O}_{4}^{--}$ & $\mathbf{C a}^{++}$ & $\mathbf{M g}^{++}$ & $\mathbf{N a}^{+}$ & $\mathbf{K}^{+}$ \\
\hline $300 \mathrm{ppm}$ & - & 2.8 & 1.3 & 0.1 & 1.6 & 1.3 & 1.1 & 0.2 \\
$1000 \mathrm{ppm}$ & - & 2.8 & 9.6 & 0.2 & 2.1 & 3.1 & 7.1 & 0.3 \\
$2000 \mathrm{ppm}$ & - & 2.8 & 21.5 & 0.5 & 2.5 & 5.9 & 15.9 & 0.5 \\
$3000 \mathrm{ppm}$ & - & 2.8 & 32.1 & 0.8 & 3.1 & 9.3 & 22.6 & 0.7 \\
$4000 \mathrm{ppm}$ & - & 2.8 & 41.9 & 1.10 & 4.02 & 11.2 & 32.22 & 0.9 \\
\hline
\end{tabular}

Table 2. The physical and chemical properties of pot soil

\begin{tabular}{|c|c|c|c|c|c|c|c|c|c|c|c|c|c|}
\hline \multicolumn{5}{|c|}{ Physical properties } & \multicolumn{9}{|c|}{ Chemical properties } \\
\hline Clay & Silt & Sand & & ure & \multicolumn{5}{|c|}{ Cation meq/L } & \multicolumn{4}{|c|}{ Anion meq/L } \\
\hline \multirow[t]{2}{*}{23.25} & 10.70 & 66.06 & Sand & clay & $\mathrm{pH}$ & $\mathrm{Ca}^{++}$ & $\mathrm{Mg}^{++}$ & $\mathrm{Na}^{+}$ & $\mathrm{K}^{+}$ & $\mathrm{Co}_{3}^{--}$ & $\mathrm{HcO}_{3}^{-}$ & $\mathrm{Cl}^{-}$ & $\mathrm{So}_{4}^{--}$ \\
\hline & & & & loam & 7.61 & 0.56 & 0.38 & 0.88 & 0.17 & 0 & 0.51 & 1.02 & 0.46 \\
\hline
\end{tabular}

Table 3. Chemical and biochemical analysis of seaweed extract according to UAD ${ }^{\circledR}$ Company.

\begin{tabular}{llllll}
\hline & Organic component & & Growth regulators & \multicolumn{2}{c}{ Macro and micro elements } \\
\hline Alganic acid & $5 \%$ & IAA & $0.03 \%$ & Organic N & $1 \%$ \\
Oligo saccharides & $3 \%$ & Cytokinins & $0.025 \%$ & $\mathrm{P}_{2} \mathrm{O}_{5}$ & $0.5 \%$ \\
Manitol & $0.001 \%$ & & $\mathrm{~K}_{2} \mathrm{O}$ & $12 \%$ \\
Zeatin & $0.003 \%$ & & $\mathrm{Fe}$ & $0.2 \%$ \\
Betaines & $0.02 \%$ & & $\mathrm{Zn}$ & $3 \%$ \\
& & & $\mathrm{Mn}$ & $1 \%$ \\
\hline
\end{tabular}

\section{Data recorded:}

A-Plant characteristics: After 80 days from transplanting, the plant physical characteristics including plant height $(\mathrm{cm})$ and leaf area $\left(\mathrm{cm}^{2}\right)$ were recorded. In addition, chemical constituents in leaf as chlorophyll A, B and carotenoids contents (mg/100g. fresh weight) were determined according to Lichtenthaler, (1987).

B- Fruits yield: Tomato fruits were harvested when reached to red ripe stage to determine total yield in weight and number of fruits per plant.

C-Fruits characteristics: A sample of five randomly fruits per treatment were used to determine the physical characteristics including fruit fresh weight $(\mathrm{g})$, size $\left(\mathrm{cm}^{3}\right)$, length $(\mathrm{cm})$ and diameter $(\mathrm{cm})$ as well as the fruits chemical constituents such total soluble solids (\%) and ascorbic acid (mg./100g.fresh weight) contents were determined by the method published in A.O.A.C (2005), beside dry matter (\%) content was calculated according to the following formula: Dry matter $(\%)=$ Dry weight/Fresh weight $* 100$.

Data were subjected to statistical analysis using the analysis of variance methods and the means of treatments were compared by using the Least Significant Different (L.S.D) at 5\% level of probability according to Snedecor and Cochran (1980).

\section{Results}

\subsection{Plant characteristics:}

Data presented in Table. 4 represent the effect of irrigation by the different levels of saline water, foliar spray with seaweed extract concentrations and their interaction on plant growth characteristics of tomato plant. The data reflected that the increase in the saline levels up to $4000 \mathrm{ppm}$ decreased the values of plant height and leaf area in spite of the difference resulted from using control level and 1000 ppm level did not reach significance, but the significant reduction was happened for the plant height in the second season. On the other hand, plant height and leaf area significantly increased with the increase in the tested applications of seaweed extract from 200 till $800 \mathrm{ppm}$. The interaction among treatments showed that the highest significant values of plant height and leaf area were observed from using control level and 1000 ppm saline level in addition to the seaweed application of $800 \mathrm{ppm}$, whereas the lowest one exerted from the level of $4000 \mathrm{ppm}$ and the untreated plants with the seaweed. The obtained data about effect of the different saline water levels, seaweed concentrations and their interaction on the studied leaf chemical characteristic (Table.5) cleared that 1000 ppm saline level gave significantly increases in leaf chlorophyll A, B and carotenoids contents, followed by significantly decreases in plants irrigated with 2000 , 
3000 and 4000 ppm saline water. On the other hand, the positive significant effects came from using all the foliar application of seaweed extract up to $800 \mathrm{ppm}$. These results reflected that the highest values in the leaf chemical characteristic detected from using the saline water level at $1000 \mathrm{ppm}$, meanwhile the lowest one was exerted from $4000 \mathrm{ppm}$ saline water and the control treatment of seaweed extract.

\subsection{Fruits yield}

Observations of the different saline water levels, seaweed concentrations and their interaction on the total yield of fruits per plant (Table .6) cleared that total yield as fruit number and weight significantly increased with exposing the plants to $1000 \mathrm{ppm}$ level, and then a significant reduction happened from using high salinity levels. On the other hand, total yield as number and weight significantly increased with the increase in the tested applications of seaweed extract from 200 till $800 \mathrm{ppm}$. In other words, the highest total yield as number and weight resulted from the plants grown in the level of $1000 \mathrm{ppm}$ and sprayed with 800 ppm seaweed, while the lowest one produced from the saline level at $4000 \mathrm{ppm}$ in the control treatment of seaweed extract.

\subsection{Fruits characteristics:}

The first remarks are that the different saline water levels, seaweed concentrations and their interaction affected the fruit physical characteristics of tomato (Table .7). The values of fruit fresh weight, size, diameter and length were increased in control treatment and the saline water level of $1000 \mathrm{ppm}$ without significant differences between them except character of fruit diameter, then followed by significantly decreased from exposing to 2000, 3000 and $4000 \mathrm{ppm}$ saline water. With respect to the effect of seaweed concentrations, it was found that fruit physical characteristics significantly increased by using seaweed concentrations until $800 \mathrm{ppm}$. The interaction among treatments reflects that the highest significant values of fruit physical characteristics were observed from using control level and the saline water level at $1000 \mathrm{ppm}$ and the seaweed application of 800 ppm, whereas the lowest one exerted from using the level of $4000 \mathrm{ppm}$ without the seaweed.

It is clear from the data shown in Table 8 that the effect of different saline water levels, seaweed concentrations and their interaction on the fruit T.S.S and dry matter contents reflected that irrigation with all the saline water levels induced significant increases in these contents compared with the control level. At the same time, the data indicated that the spray with concentration of seaweed extract at $800 \mathrm{ppm}$ had a significant increase in T.S.S and dry matter contents. The interaction effect between saline water levels and seaweed extract concentrations observed that the highest significant values of T.S.S and dry matter contents recorded from using the saline level of 4000 ppm and the concentration of $800 \mathrm{ppm}$ seaweed extract, while the lowest value appeared in the plants subjected to the control level of $300 \mathrm{ppm}$ and the untreated plants with the seaweed.

With respect to the effect of the different saline levels, concentrations of seaweed extract and their interaction on fruit ascorbic acid content (Table .8) denoted that there was a significant increase in fruit ascorbic acid content with increasing saline water up to $2000 \mathrm{ppm}$, then a significant decrease happened in the levels of 3000 and $4000 \mathrm{ppm}$. Evidences from seaweed extract concentrations indicated that this content significantly increased with the increase in the applied concentrations of seaweed extract up to 800 ppm. Hence, the best results in the content of ascorbic acid was achieved from using 2000 ppm saline water in the plants sprayed with the concentration of 800 ppm seaweed extract and the opposite was true from using $4000 \mathrm{ppm}$ and unsprayed plants with seaweed extract.

\section{Discussion}

The present work aimed to mitigate the adverse effects of salt stress on growth and yield of tomato by using the foliar spray with the different concentrations of seaweed extract. Trends of the studied physical characters showed that the plant height, leaf area, fruit fresh weight, size, length and diameter, in addition to total yield fruit per plant as fruit number and weight decreased from exposing to high levels of salinity up to $4000 \mathrm{ppm}$. Hence, the harmful effects of salinity on growth of tomato plant may be due to decline water uptake (Kaydan accumulate specific ions such as $\mathrm{Na}$ and $\mathrm{Cl}$ in the cytoplasm which inhibits the production of chlorophyll in leaves (Al-Safadi and Faoury, 2004), reduction in light utilization efficiency due to partial stomatal closure and simultaneously decreased $\mathrm{Co}_{2}$ diffusion which in turn induced decreasing plant photosynthesis and thereby limits the supply of carbohydrate needed for growth (Schwarz et al., 2002). The other physiological reason for our results indicated that the increase in salinity levels plays a pivotal role in disturbing the cellular functions of tomato plant (Babu et al., 2012) which led to the inhibiting of cell division and enlargement and this in turn might contribute affect all morphological parameters of growing plants and much for decreasing in the fruits characteristics and quality. Here, it is worthy to say that reduction of tomato fruit yield under high salinity conditions up to 4000 ppm may be attributed mainly, to reduction in average fruit weight, size and number.

Concerning the changes occurred in the chemical characteristics, it is obvious that the leaf chlorophyll A, B and carotenoids contents were decreased with increasing saline water levels up to $4000 \mathrm{ppm}$. This result may be related to enhance activity of chlorophyllase, which might be due to the negative effects of salinity on some ions uptake, for example $\mathrm{Mg}$ and $\mathrm{Fe}$, which were included in the chloroplast formation (Zhang et al., 2016).

Regarding the increase in fruit ascorbic acid content as a result for increasing the saline water levels up to 
2000 ppm comparing with the control level of 300 ppm, this feature may be linked to the key role of ascorbic acid as a strong antioxidant for protecting the plant from the detrimental effects of salinity (Ali and Ismail, 2014). At the same time, the increase in the content of total soluble solids in the tomato fruit due to the increase in the saline water levels up to 4000 ppm may be attributed to the fact the plant push to regulate certain metabolic activity under the salinity stress by degradation of polysaccharides to simple sugars thereby arise in T.S.S which play an important role in osmotic adjustment in plant (Benbella, 1999). In this concern, osmotic adjustment is a mechanism to maintain water relations under osmotic stress. Moreover, salinity stress inhibits water importation to the fruit, and which leads to increase concentration of soluble solids in fruit (Zhang et al., 2016). Also, the increase of dry matter of tomato fruit with the increasing water salinity up to $4000 \mathrm{ppm}$ may be caused by the reduction of the import of water by the fruit in saline conditions (Sakamoto et al., 1999).

The plants irrigated with the different of saline water levels and sprayed with the different concentrations of seaweed extract appeared that using the saline level of $1000 \mathrm{ppm}$ and the seaweed concentration of $800 \mathrm{ppm}$ had the highest values in the physical characteristics of plant and fruits such as plant height and leaf area, fruit fresh weight, size, length and diameter, in addition to total yield per plant as fruit number and weight. To discuss this trend in the previous results, it is well to say that spraying with the different concentrations of seaweed extract promoted plant growth and increased stress tolerance. Hence, these results may be due to containing seaweed extract to some components such as macro- and micro element nutrients, amino acids, vitamins, cytokinins and auxins like growth substances in which affect cellular metabolism in treated plants leading to enhance growth and crop yield (Zewail, 2014). In this respect, the highest total yield as number and weight resulted from the plants grown in the level of $1000 \mathrm{ppm}$ and sprayed with 800 ppm seaweed could be conducted with the beneficial effect of seaweed on increasing vegetative growth characteristics (Table 4) and the chlorophyll formation, as well (Table 5). Therefore, under these circumstances the translocation of different photosynthetic to fruits is being maximized thereby, increase the fruits yield would be expected. Concerning the changes in the chemical contents of tomato plant and fruit, The results indicated the highest values of leaf chlorophyll A, B and carotenoids contents came from using 1000 ppm saline level and the foliar spray with seaweed extract at $800 \mathrm{ppm}$.This results may be due to the benefit effect of seaweed extract in protecting chlorophyll degradation which might be caused to betaine and betaine-like compounds present in seaweed. In plants, betaines serve as a compatible solute that alleviates osmotic stress induced by salinity stress (Khan et al., 2009). Nevertheless, this increase in the photosynthetic pigments may be due to the presence of magnesium in seaweed extract which is the chief constituent for chlorophyll synthesis or due to increase in number and size of the chloroplast and better grana development (Ramya et al., 2010).

At the same time, the best results in the content of ascorbic acid in fruit achieved from using the level $2000 \mathrm{ppm}$ of saline water in the plants sprayed with the concentration of $800 \mathrm{ppm}$ seaweed extract.This result confirmed the important function of seaweed extract in the tolerance to salinity because application of seaweed extract led to increase the activity antioxidant enzymes in plant cells which scavenges reactive oxygen species. Therefore, many researchers have reported that seaweed extracts enhance the ascorbate peroxidase activities (Ayad, 1998); demonstrating the strong antioxidant properties of seaweeds which have been correlated to bioactive compounds (Meenakshi et al. 2009). Also, it was found that seaweed extract stimulate the biosynthesis of ascorbic acid in chloroplast which protect photosynthetic apparatus (Zhang and Schmidt, 2000).

At the same time, the foliar seaweed extract at 800 ppm was the most effective leading to increase TSS and dry matter contents in fruit for plants subjected to the irrigation with the different saline levels. This result could be attributed to the role of seaweed extract in enhancing many physiological processes and leading to increase resistance to salinity stresses (Mattner et al., 2013). Our major interest in the present work was to assess the effect of the different concentrations of irrigation with saline agriculture drainage water, seaweed extract and their combination on growth and yield of tomato. This study indicated that seaweed extract application of $800 \mathrm{ppm}$ in tomato plants grown under salinity conditions up to $1000 \mathrm{ppm}$ had positively influenced by improving vegetative growth and fruit yield and its quality. Hence, the beneficial effect of seaweed extract plausible that the seaweed components exhibit synergistic activity in physiological responses and stress alleviation. 
Table 4. Effect of the different saline water levels, seaweed extract concentrations and their interaction on the plant physical characteristics of tomato during the two winter seasons of 2018-2019 and 2019-2020.

\begin{tabular}{|c|c|c|c|c|c|c|c|c|c|c|c|c|c|}
\hline \multirow{4}{*}{\multicolumn{2}{|c|}{$\begin{array}{c}\text { Seaweed extract } \\
\text { Concs.ppm(B) }\end{array}$}} & \multicolumn{12}{|c|}{ 2018-2019 season } \\
\hline & & \multicolumn{12}{|c|}{ Salinity levels ppm (A) } \\
\hline & & \multicolumn{5}{|c|}{ Plant height (cm) } & \multicolumn{7}{|c|}{ Leaf area $\left(\mathbf{m}^{2}\right)$} \\
\hline & & Cont. & 1000 & 2000 & 3000 & 4000 & Mean & Cont. & 1000 & 2000 & 3000 & 4000 & Mean \\
\hline Cont. & & 177.65 & 175.70 & 159.60 & 130.63 & 97.97 & 148.31 & 119.21 & 116.58 & 113.85 & 110.96 & 104.44 & 113.01 \\
\hline 200 & & 180.27 & 177.60 & 164.12 & 137.27 & 106.20 & 153.09 & 122.51 & 119.39 & 116.5 & 112.62 & 106.26 & 115.46 \\
\hline 400 & & 184.30 & 181.00 & 171.10 & 145.00 & 112.80 & 158.84 & 124.11 & 123.08 & 118.20 & 114.14 & 108.06 & 117.52 \\
\hline 800 & & 187.90 & 185.00 & 176.43 & 150.50 & 120.20 & 164.01 & 128.10 & 127.90 & 119.39 & 115.43 & 110.15 & 120.19 \\
\hline Mean & & 182.53 & 179.83 & 167.81 & 140.85 & 109.29 & & 123.48 & 121.74 & 116.99 & 113.29 & 107.23 & \\
\hline $\begin{array}{c}\text { L.S.D at } \\
\mathbf{5 \%}\end{array}$ & $\begin{array}{c}\mathbf{A} \\
\mathbf{B} \\
\mathbf{A} \mathbf{X} \mathbf{B} \\
\end{array}$ & \multicolumn{5}{|c|}{$\begin{array}{l}1.94 \\
3.04\end{array}$} & & \multicolumn{6}{|c|}{$\begin{array}{l}0.91 \\
2.00\end{array}$} \\
\hline & & \multicolumn{12}{|c|}{ 2019-2020 season } \\
\hline \multicolumn{2}{|c|}{$\begin{array}{l}\text { Seaweed extract } \\
\text { Concs.ppm(B) }\end{array}$} & Cont. & 1000 & 2000 & 3000 & 4000 & Mean & Cont. & 1000 & \multicolumn{2}{|l|}{2000} & 4000 & Mean \\
\hline Cont. & & 180.2 & 177.63 & 169.46 & 158.6 & 139.36 & 165.05 & 114.91 & 112.26 & 111.15 & 104.01 & 100.56 & 108.58 \\
\hline 200 & & 183.44 & 179.91 & 171.99 & 165.4 & 143.2 & 168.79 & 115.23 & 114.77 & 114.65 & 106.23 & 102.69 & 110.71 \\
\hline 400 & & 187.37 & 183.8 & 175.44 & 171.41 & 145.21 & 172.65 & 121.18 & 119.92 & 115.96 & 109.20 & 104.41 & 114.13 \\
\hline 800 & & 190.10 & 188.92 & 180.43 & 173.20 & 146.72 & 175.87 & 122.84 & 121.10 & 119.04 & 111.61 & 106.23 & 116.16 \\
\hline Mean & & 185.28 & 182.57 & 174.33 & 167.15 & 143.62 & & 118.54 & 117.01 & 115.20 & 107.76 & 103.47 & \\
\hline $\begin{array}{r}\text { L.S.D at } \\
\mathbf{5 \%}\end{array}$ & $\begin{array}{c}\text { A } \\
\text { B } \\
\mathbf{A} \text { X B }\end{array}$ & & & $\begin{array}{l}1.82 \\
1.41 \\
2.55\end{array}$ & & & & & & & & & \\
\hline
\end{tabular}


Table 5. Effect of the different saline water levels, seaweed extract concentrations and their interaction on the leaves chemical constituents of tomato during the two winter seasons of 2018-2019 and 2019-2020.

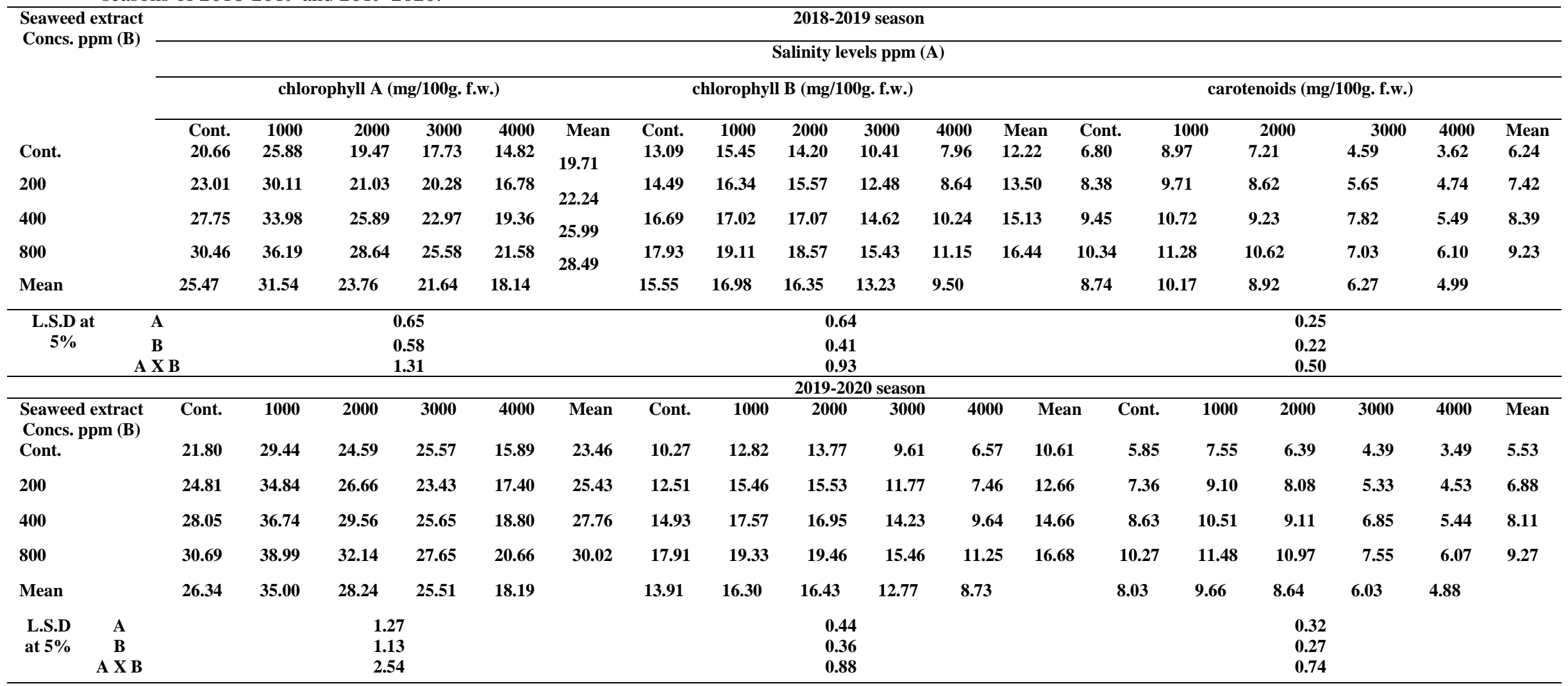


Table 6. Effect of the different saline water levels, seaweed extract concentrations and their interaction on total yield of tomato during the two winter seasons of $2018-2019$ and 2019-2020.

\begin{tabular}{|c|c|c|c|c|c|c|c|c|c|c|c|c|c|}
\hline \multirow{2}{*}{\multicolumn{2}{|c|}{$\begin{array}{c}\text { Seaweed extract } \\
\text { Concs. ppm (B) }\end{array}$}} & \multicolumn{12}{|c|}{ 2018-2019 season } \\
\hline & & \multicolumn{12}{|c|}{ Salinity levels ppm (A) } \\
\hline & & \multicolumn{6}{|c|}{ Total yield in number /plant } & \multicolumn{6}{|c|}{ Total yield in weight /plant (g) } \\
\hline Cont. & & $\begin{array}{l}\text { Cont. } \\
13.15\end{array}$ & $\begin{array}{r}1000 \\
13.91\end{array}$ & $\begin{array}{l}2000 \\
12.43\end{array}$ & $\begin{array}{c}3000 \\
12.11\end{array}$ & $\begin{array}{l}4000 \\
11.99\end{array}$ & $\begin{array}{l}\text { Mean } \\
12.72\end{array}$ & $\begin{array}{c}\text { Cont. } \\
926.55\end{array}$ & $\begin{array}{c}1000 \\
1001.52\end{array}$ & $\begin{array}{c}2000 \\
794.53\end{array}$ & $\begin{array}{c}3000 \\
670.17\end{array}$ & $\begin{array}{c}4000 \\
623.24\end{array}$ & \begin{tabular}{|c|} 
Mean \\
803.20
\end{tabular} \\
\hline 200 & & 13.9 & 14.6 & 13.12 & 12.9 & 12.37 & 13.38 & 1026.52 & 1090.62 & 978.62 & 765.10 & 717.46 & 915.66 \\
\hline 400 & & 14.9 & 15.27 & 13.55 & 13.36 & 12.67 & 13.95 & 1180.08 & 1235.34 & 1056.22 & 831.53 & 770.59 & 1014.75 \\
\hline 800 & & 16.04 & 16.23 & 14.28 & 13.9 & 13.39 & 14.77 & 1345.44 & 1364.78 & 1144.54 & 1002.05 & 844.37 & 1140.24 \\
\hline Mean & & 14.49 & 15.00 & 13.35 & 13.07 & 12.61 & & 1119.64 & 1173.07 & 993.48 & 817.21 & 738.92 & \\
\hline \multirow{3}{*}{$\begin{array}{c}\text { L.S.D at } \\
5 \%\end{array}$} & $\mathbf{A}$ & \multicolumn{6}{|c|}{0.28} & \multicolumn{6}{|c|}{$\mathbf{5 0 . 8 1}$} \\
\hline & $\begin{array}{c}\text { B } \\
\mathbf{A} \mathbf{X} \text { B } \\
\end{array}$ & \multicolumn{6}{|c|}{$\begin{array}{l}0.22 \\
0.47\end{array}$} & \multicolumn{6}{|c|}{$\begin{array}{l}44.28 \\
57.01 \\
\end{array}$} \\
\hline & & \multicolumn{12}{|c|}{ 2019-2020 season } \\
\hline \multicolumn{2}{|c|}{$\begin{array}{l}\text { Seaweed extract } \\
\text { Concs.ppm (B) }\end{array}$} & Cont. & 1000 & 2000 & 3000 & 4000 & Mean & Cont. & 1000 & 2000 & 3000 & 4000 & Mean \\
\hline \multicolumn{2}{|c|}{ Cont. } & 13.15 & 13.91 & 12.43 & 12.11 & 11.99 & 12.72 & 953.38 & 1042.28 & 813.79 & 732.17 & 603.34 & 828.99 \\
\hline \multicolumn{2}{|l|}{200} & 13.9 & 14.6 & 13.12 & 12.9 & 12.37 & 13.38 & 1057.10 & 1117.05 & 938.74 & 812.44 & 666.12 & 918.29 \\
\hline \multicolumn{2}{|l|}{400} & 14.9 & 15.27 & 13.55 & 13.36 & 12.67 & 13.95 & 1205.56 & 1264.20 & 1004.73 & 876.95 & 715.86 & 1013.46 \\
\hline \multicolumn{2}{|l|}{800} & 16.04 & 16.23 & 14.28 & 13.9 & 13.39 & 14.77 & 1351.53 & 1383.93 & 1117.12 & 969.53 & 794.70 & 1123.36 \\
\hline \multicolumn{2}{|l|}{ Mean } & 14.50 & 15.00 & 13.35 & 13.07 & 12.61 & & 1141.89 & 1201.86 & 968.60 & 847.77 & 695.00 & \\
\hline $5 \%$ & $\begin{array}{l}\text { A } \\
\text { B } \\
\mathbf{X} \text { B }\end{array}$ & & & & & & & & & $\begin{array}{l}\mathbf{4 2} \\
\mathbf{3 5} \\
\mathbf{5 0}\end{array}$ & & & \\
\hline
\end{tabular}


Table 7. Effect of the different saline water levels, seaweed extract concentrations and their interaction on the fruit physical characteristics of tomato during the two winter seasons of 2018-2019 and 2019- 2020.

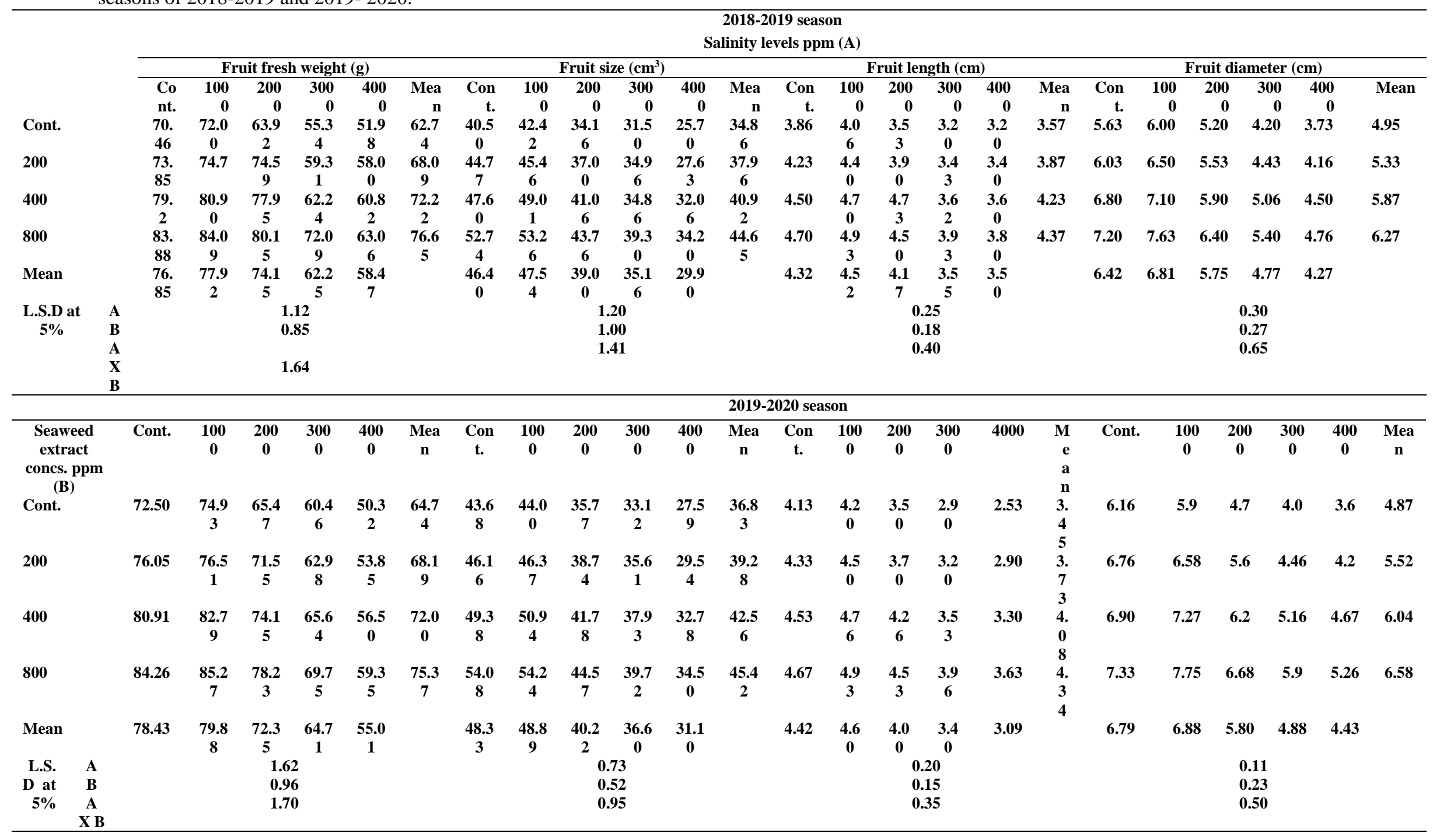


Table 8. Effect of the different saline water levels, seaweed extract concentrations and their interaction on the fruit chemical constituents of tomato during the two winter seasons of 2018-2019 and 2019-2020.

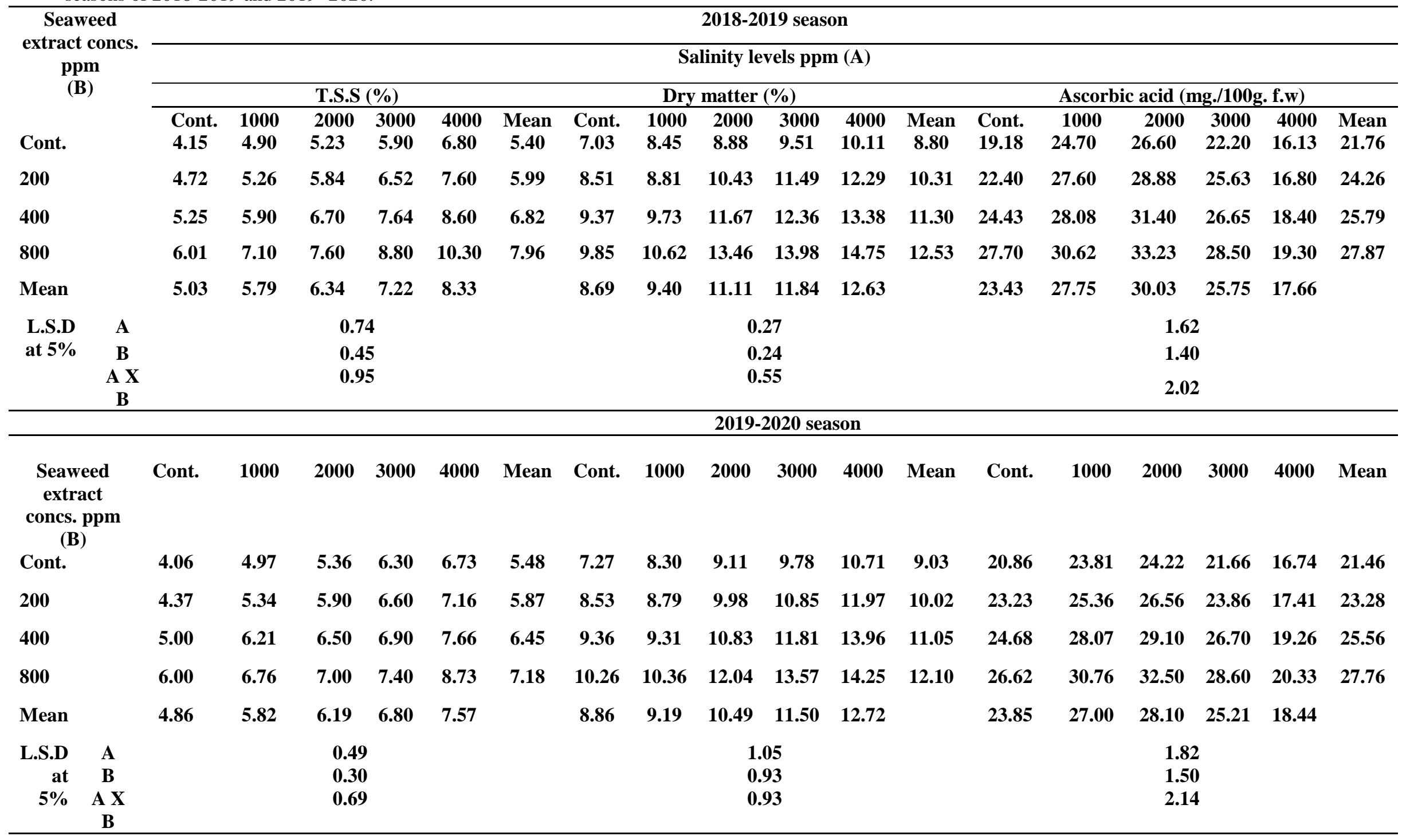




\section{References}

Ali, H. E. M. and Ismail, G.S.M. (2014). Tomato fruit quality as influenced by salinity and nitric oxide. Turk J. Bot., (38):122-129

Al-Safadi, B. and Faoury, H. (2004). Evaluation of salt tolerance in Garlic (Allium sativum L.) cultivars using in vitro techniques. Advan. Horti. Sci., (3):115-120.

Association of Official Methods of Analytical Chemists (2005). Official Methods of Analysis $15^{\text {th }}$ ed., Published by A.O.A.C Washington, D.C., U.S.A.

Ayad, J.Y. (1998). The effect of seaweed (Ascophyllum nodosum) extract on antioxidant activities and drought tolerance of tall fescue (Festuca arundinacea Schreb.). Dissertation, Texas Tech Univ.

Babu, M. A., Singh, D. and Gothandam, K. M. (2012). The effect of salinity on growth, hormones and mineral elements in leaf and fruit of tomato cultivar pkm1. J. Anim. Plant Sci., (22): 159-164

Benbella, M. (1999). Response of five sunflower genotypes (Helianthus annus L.) to different concentrations of sodium chloride. Helia., (30):125-138.

Food and Agriculture Organization of united nations (FAO), Economic and social development: The statistical division,(2018). http://faostat.fao.orgl.

Foolad, M. R. (2004). Recent advances in genetics of salt tolerance in tomato. Plant Cell Tiss. Org., (76): 101-119.

Hassan, A.A. (1988). Tomato. Al-Dar Al Arabia Lil Nashr Wa Al-Tawzeia, Cairo, Egypt, (In Arabic).

Hernández-Herrera, R. M., Santacruz-Ruvalcaba F., Ruiz-López M.A., Norrie, J. and HernándezCarmona G. (2014). Effect of liquid seaweed extracts on growth of tomato seedlings (Solanum lycopersicum L.). J. Appl. Phycol., (26):619-628.

Kaydan, D. and Okut, M.Y. (2007). Effects of salicylic acid on the growth and some physiological characters in salt stressed wheat (Triticum aestivum L.). Tarim Bİlimleri Dergisi., (2): 114-119

Khan, W., Rayirath, U.P., Subramanian, S., Jithesh, M.N., Rayorath, P., Hodges, D.M., Critchley, A.T., Craigie, J.S., Norrie, J. and Prithivira, B. (2009). Seaweed extracts as bio stimulants of plant growth and development. J. Plant Growth Regul., (28): 386-399.

Lichtenthaler, H.K. (1987). Chlorophylls and Carotenoids: Pigments of Photosynthetic
Biomembranes. Methods in Enzymology, (148): 350-382.

Mattner, S.W., Wite, D., Riches, D.A., Porter, I.J. and Arioli, T. (2013). The effect of kelp extract on seedling establishment of broccoli on contrasting soil types in southern Victoria, Australia. Biol. Agric. Horti., 29: 258-270.

Meenakshi, S., Manicka, D. G., Tamil, S., Arumugam, M. and Balasubramanian, T. (2009). Total flavonoid and in vitro antioxidant activity of two seaweeds of Rameshwaram Coast. Global Journal of Pharmacology, (3): 59-62.

Ramya, S. S., Nagaraj, S. and Vijayanand, N. (2010). Biofertilizing efficiency of brown and green algae on growth, biochemichal and yield parameters of Cyamopsis tetragonolaba (L.) Taub. Recent Res. Sci. Techno, (2):45-52.

Sakamoto, Y., Watanabe, S. Nakashima, T. and Okano, K. (1999). Effects of salinity at two ripening stages on the fruit quality of single-truss tomato grown in hydroponics. J. Hort. Sci. Bio., (74): 690-693.

Schwarz, D., Klaring, H.P., Iersel, M. W. V. and Ingram, K. T. (2002). Growth and photosynthetic response of tomato to nutrient solution concentration at two light levels. J. Amer. Soc. Hort. Sci., (127): 984-990.

Snedecor, G.W. and Cochran, W.G. (1980). Statistical Methods ( $8^{\text {th }}$ Ed.), Iowa Stat. Univ. Press. USA.

Zewail, R. M. Y. J. (2014). Effect of seaweed extract and amino acids on growth and productivity and some biocostituents of commen bean (Phaseolus vulgaris L.) plants. Plant Production, Mansoura Univ., (5): 1441 - 1453

Zhang, P., Senge, M. and Dai, Y. (2016). Effects of salinity stress on growth, yield, fruit quality and water use efficiency of tomato under hydroponics system. Revi. Agri. Sci., (4): 46- 55

Zhang S., Weng, J., Pan J., Tu, T., Yao, S. and Xu, C. (2003). Study on the photogeneration of superoxide radicals in Photosystem II with EPRspin trapping techniques. Photosynth Res., (75):41-48.

Zhang, X. and Schmidt, R.E. (2000). Hormonecontaining products' impact on antioxidant status of tall fescue and creeping bent grass subjected to drought. Crop Sci., (40): 1344-1349.

Zhu, J.K. (2001). Plant salt tolerance. Trends Plant Sci., (6): 66-71. 


\section{تقييم تأثير مستخلص الطحالب البحرية على نمو ومحصول نباتات الطماطم تحت ظروف إجهاد الملوحة عشماوي السيد عشماوي1 و أحمد حمدي محمد عبد الواحدا و أسعد حسن عواد حسن \\ 1- قسم البساتين - كلية النراعة - جامعة الازهر - القاهرة}

أجريت هذه التجربة في كلية الزراعة، جامعة الأزهر ، مدينة نصر ، القاهرة، مصر خلال الموسم الشتوي 2018-2019 و 2019-2020

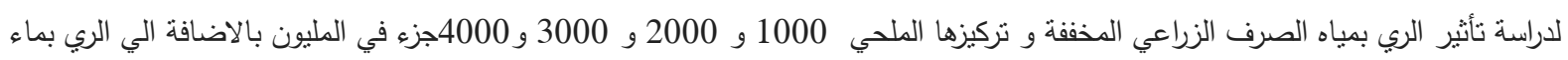

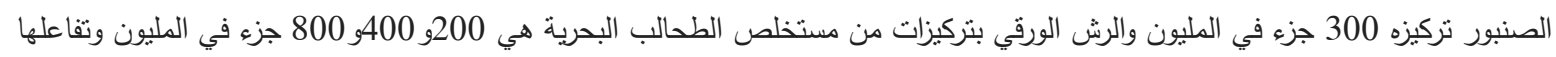
على النمو والمحصول وجودة ثمار الطماطم صنف ماجي هجين تحت ظروف الصوبة البلاستيكية. أوضحت النتائج أن ارتفاع النبات و مساحة

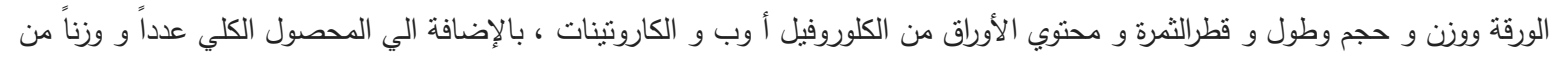
الثمار زادت معنوياً بإستخدام التركيز الملحي في ماء الري عند 1000 جزء في المليون و الرش الورقي بمستخلص الطحالب البحرية عند نركيز

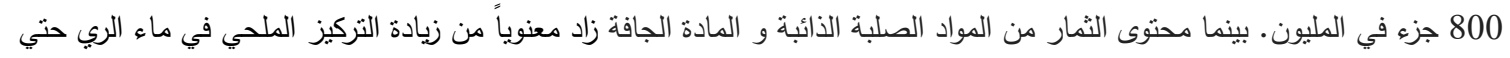

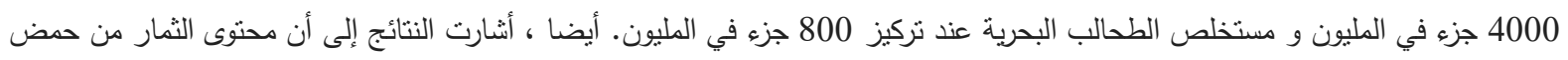

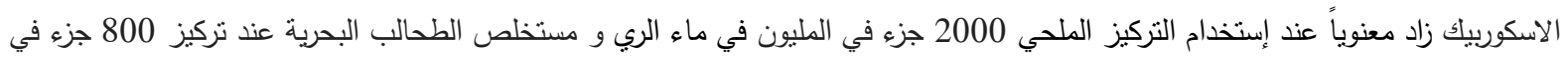
المليون. و يوصي البحث بناء علي النتائج المتحصل عليها أن تطبيق الرش الورقي بمستخلص الطحالب البحرية عند تركيز 800 جزء في المليون كان الأكثر تأثنر لتقليل الاثر الضار لملوحة مياة الري علي نمو و محصول الطماطم. لطئ. 